\title{
SANITASI LINGKUNGAN BERBASIS INFRASTRUKTUR PEMUKIMAN YANG BERNILAI EKONOMIS DI DESA SEKOTONG TENGAH
}

\author{
Ahmadi ${ }^{1}$, Andriyana ${ }^{1}$, Hilda Seftiana ${ }^{1}$, Yayuk Silpiana Sari ${ }^{1}$, Darosa Mahaparsa ${ }^{2}$, Sri Usmayati ${ }^{3}$, \\ Lalu Tomi Farizal A. ${ }^{4}$, Lailatul Ulfah ${ }^{4}$, Nurul Awaliah ${ }^{4}$, Etika Ratnasari 5, Nandita Citra Widiantari ${ }^{5}$, \\ Sri Wahyuni ${ }^{5}$, Sukardi ${ }^{6 *}$.
}

${ }^{1}$ Fakultas Ekonomi dan Bisnis, Universitas Mataram Jl. Majapahit No. 62 Mataram, NTB.

${ }^{2}$ Fakultas Hukum, Universitas Mataram JI. Majapahit No. 62 Mataram, NTB.

${ }^{3}$ Fakultas Teknologi Pangan dan Agroindustri,, Universitas Mataram JI. Majapahit No. 62 Mataram, NTB.

${ }^{4}$ Fakultas Teknik, Universitas Mataram Jl. Majapahit No. 62 Mataram, NTB.

${ }^{5}$ Fakultas Pertanian, Universitas Mataram JI. Majapahit No. 62 Mataram, NTB.

${ }^{6}$ Fakultas Keguruan dan IImu Pengetahuan, Universitas Mataram JI. Majapahit No. 62 Mataram, NTB.

${ }^{*}$ Co-author: Sukardi.fkip@unram.ac.id

\begin{abstract}
ABSTRAK. Kesehatan lingkungan merupakan faktor penting dalam kehidupan sosial kemasyarakatan, oleh karena itu diadakan KKN Infrastruktur dengan tema "Peningkatan dan Pengolahan Sanitasi Lingkungan Berbasis Infrastruktur Permukiman yang bernilai ekonomis" di Desa Sekotong Tengah. Bertujuan untuk meningkatkan kemampuan dan wawasan mahasiswa sebagai bekal hidup di masyarakat setelah lulus studi. Metode pelaksanaan yang diterapkan pada KKN Infrastruktur di Desa Sekotong Tengah adalah Metode PAR (Participatory Action Research). PAR sendiri adalah suatu cara membangun jembatan untuk menghubungkan orang. Jenis penelitian ini adalah suatu proses pencarian pengembangan pengetahuan praktis dalam memahami kondisi sosial, politik, lingkungan, atau ekonomi. Dimulai dengan metode persiapan, observasi, pelatihan dan pembinaan. Metode evaluasi pelaksanaan program kegiatan KKN ditinjau dari keberlangsungan program kerja dan keefektifan keberlangsungan program pada sasaran dari setiap program kerja. Untuk itu diadakannya 2 program kerja utama dan 2 program kerja tambahan. Dengan bertumpu pada sosialisasi dan pelatihan terhadap sanitasi lingkungan, menjadi barang yang bernilai ekonomis.
\end{abstract}

Kata Kunci: Kesehatan lingkungan, Pengolahan Sanitasi Lingkungan, Infrastruktur Pemukiman, Bernilai Ekonomis.

ABSTRACT. Environmental health is an important factor in social community life, therefore an Infrastructure Community Service Program was held with the theme "Improvement and Management of Environmental Sanitation Based on Settlement Infrastructure with economic value" in Desa Sekotong Tengah. Aims to improve the ability and insight of students as a provision to live in the community after graduating from study. The implementation method applied to the Infrastructure KKN in Desa Sekotong Tengah is the PAR (Participatory Action Research) Method. PAR itself is a way to build bridges to connect people. This type of research is a process of finding practical knowledge development in understanding social, political, environmental, or economic conditions. Starting with the methods of preparation, observation, training and coaching. The method of evaluating the implementation of the KKN program activities in terms of the sustainability of the work program and the effectiveness of the program's sustainability on the targets of each work program. For this reason, 2 main work programs and 2 additional work programs are held. By relying on socialization and training on environmental sanitation, it becomes an economic value item. 
Keywords: Environmental health, Environmental Sanitation Processing, Settlement Infrastructure, Economic Value.

\section{PENDAHULUAN}

Kesehatan lingkungan merupakan faktor penting dalam kehidupan sosial kemasyarakatan, bahkan merupakan salah satu unsur penentu atau determinan dalam kesejahteraan penduduk. Di mana lingkungan yang sehat sangat dibutuhkan bukan hanya untuk meningkatkan derajat kesehatan masyarakat, tetapi juga untuk kenyamanan hidup dan meningkatkan efisiensi kerja dan belajar. Hasil penelitian menunjukkan bahwa tingginya angka kematian bayi pada suatu daerah disebabkan karena faktor perilaku (perilaku perawatan pada saat hamil dan perawatan bayi, serta perilaku kesehatan lingkungan ) dan faktor kesehatan lingkungan. ( Mutmainna, 2012).

Pada masa yang datang pemerintah lebih fokus pada pelaksanaan pembangunan yang berkelanjutan dan pengembangan wilayah yang berkesadaran lingkungan, sementara pihak pengguna infrastruktur dalam hal ini masyarakat secara keseluruhan harus disiapkan dengan kesadaran lingkungan yang lebih baik (tahu sesuatu atau tahu bersikap yang semestinya) Masa datang kita dihadapkan dengan penggunaan IPTEK yang lebih maju dan lebih kompleks yang memerlukan profesionalisme yang lebih baik dengan jenjang pendidikan yang memadai. (Mutmainna, 2012).

Di samping itu dalam proses pembangunan masa datang, diperlukan adanya teknologi kesehatan lingkungan yang menitik beratkan upayanya pada metodologi mengukur dampak kesehatan dari pencemaran yang ditimbulkan oleh adanya pembangunan, Indikator ini harus mudah, murah untuk diukur juga sensitif menunjukkan adanya perubahan kualitas lingkungan. (Mutmainna, 2012).

Ruang lingkup kesehatan lingkungan antara lain mencakup perumahan, pembuangan kotoran manusia (tinja), penyediaan air bersih, pembuangan sampah, pembuangan air kotor (air limbah), rumah hewan ternak (kandang) dan sebagainya. Adapun yang dimaksud dengan usaha kesehatan lingkungan adalah suatu usaha untuk memperbaiki atau mengoptimumkan lingkungan hidup manusia agar merupakan media yang baik untuk terwujudnya kesehatan optimum bagi manusia yang hidup di dalamnya. Usaha memperbaiki atau meningkatkan kondisi lingkungan ini dari masa ke masa dan dari masyarakat satu ke masyarakat yang lain bervariasi dan bertingkat-tingkat, dari yang paling sederhana (primitif) sampai kepada yang paling mutakhir (modern). Dengan perkataan lain bahwa teknologi di bidang kesehatan lingkungan sangat bervariasi, dari teknologi primitif, teknologi menengah (teknologi tepat guna) sampai dengan teknologi mutakhir. (Berita TKSK Pidie, 2012).

Usaha peningkatan kesehatan lingkungan yang umumnya dikenal dengan sebutan sanitasi merupakan salah satu tindakan yang dimaksudkan untuk pemeliharaan kesehatan maupun pencegahan penyakit pada lingkungan fisik, sosial, ekonomi, budaya dan sebagainya (Notoatmodjo, 2003). Sanitasi dalam bahasa Inggris berasal dari kata sanitation yang diartikan sebagai penjagaan kesehatan (Echols dan Shadily, 2003). Ehler dan Steel dalam Anwar (1999) mengemukakan bahwa sanitasi adalah usaha-usaha pengawasan yang ditujukan terhadap faktor lingkungan yang dapat menjadi mata rantai penularan penyakit. 
Menurut Arne Naess, krisis lingkungkungan hidup dewasa ini hanya bisa diatasi dengan melakukan perubahan cara pandang dan perilaku manusia terhadap alam secara fundamental dan radikal. Dibutuhkan sebuah pola hidup atau gaya hidup baru yang tidak hanya menyangkut orang perorang, tetapi tetapi juga budaya masyarakat secara keseluruhan. Artinya, dibutuhkan etika lingkungan menuntun manusia untuk berinteraksi secara baru dalam alam semesta. Dengan ini mau dikatakan bahwa krisis lingkungan hidup global yang kita alami dewasa ini sebenarnya bersumber pada kesalahan fundamental-filosofis dalam pemahaman atau cara pandang manusia mengenai dirinya, alam, dan tempat manusia dalam keseluruhan ekosistem. Perilaku yang keliru terhadap alam.Manusia keliru memandang alam dan keliru menempatkan diri dalam konteks alam semesta seluruhnya (Maghfiroh, 2016)

Salah satu masalah terbesar negara Indonesia saat ini adalah masalah sampah. Total jumlah sampah di beberapa provinsi di Indonesia cenderung terus meningkat dari tahun ke tahun. Sebagai contoh, Tahun 2000 jumlah sampah di Jawa Barat adalah sekitar 10,00 juta ton dan meningkat sampai 11,13 juta ton di tahun 2007. Tabel 2.1 memperlihatkan jumlah sampah di beberapa provinsi yang meningkat dari tahun 2000 sampai tahun 2006.

Tabel 1.1 Produksi Sampah di Beberapa Provinsi di Indonesia dari Tahun 2000 sampai Tahun 2006

\begin{tabular}{ccccc|c}
\hline No & Provinsi & \multicolumn{4}{c}{ Produksi sampah (juta ton) } \\
\cline { 3 - 6 } & & $\mathbf{2 0 0 0}$ & $\mathbf{2 0 0 2}$ & $\mathbf{2 0 0 4}$ & $\mathbf{2 0 0 6}$ \\
\hline 1 & Jawa Barat & 10,00 & 10,37 & 10,75 & 11,13 \\
\hline 2 & Jawa Timur & 9,73 & 9,82 & 9,91 & 9,99 \\
\hline 3 & Jawa Tengah & 8,74 & 8,82 & 8,89 & 8,96 \\
\hline 4 & Sumatra Utara & 3,26 & 3,35 & 3,44 & 3,53 \\
\hline 5 & DKI Jakarta & 2,34 & 2,38 & 2,42 & 2,45 \\
\hline \multicolumn{5}{c}{ (Sumber: Kementrian Lingkungan Hidup 2008b) }
\end{tabular}

Cakupan penanganan sampah oleh Pemerintah dirasakan sangat rendah. Sampah yang berhasil dikumpulkan oleh petugas kebersihan di Indonesia hanya sekitar 16,7 juta ton per tahun. Di sisi lain, sampah yang tidak terkumpul oleh petugas dinas terkait terhitung sekitar 116 juta ton pertahun, perbedaannya sangat signifikan (Kementrian Lingkungan Hidup, 2008b). Hal ini terjadi karena masih banyaknya warga Indonesia yang belum terlayani oleh jasa pengelolaan sampah. Sebagian besar sampah rumah tangga di Indonesia kurang begitu dimanfaatkan dan cenderung diangkut ke Tempat Pembuangan Sementara (TPS) dan Akhir Tempat Pembuangan (TPA). Faktanya, hanya sebagian kecil dari sampah rumah tangga yang dikonversi menjadi komoditas yang memiliki nilai ekonomi lebih, sebagai contoh hanya 7,15 \% dari sampah yang terkumpul dikonversi menjadi pupuk. Implikasinya, kebanyakan sampah dikirim ke TPA, sekitar 60\% dari TPA di Indonesia akan mencapai batas kapasitas maksimum pada tahun 2015 (Kementrian Lingkungan Hidup, 2008b).

Penyelenggaraan penyehatan lingkungan pada tempat-tempat umum merupakan upaya yang dilakukan untuk mengamankan lingkungan melalui pengawasan dan perbaikan kualitas kesehatan lingkungan. Salah satu yang merupakan bagian dari penyehatan lingkungan tersebut adalah Pasar. Menurut Peraturan Menteri Perdagangan Republik Indonesia Nomor 53/M DAG/PER/12/2008 Tahun 
2008 pasar adalah suatu area tempat jual beli barang dengan jumlah penjual lebih dari satu baik yang disebut sebagai pusat perbelanjaan, pasar tradisional, supermarket, pertokoan, mall, plaza, pusat perdagangan maupun sebutan lainnya. (Wahyudin, 2018).

Untuk di NTB sendiri sudah ada bank sampah yang di dirikan oleh para penggiat lingkungan, yang di beri nama Bank Sampah NTB Mandiri. Bank Sampah NTB Mandiri didirikan oleh Mbak Aisyah Odist pada tahun 2011 silam. Hingga kini, di Bank Sampah yang didirikannya, bungsu dari 11 bersaudara ini telah menjalin kerjasama dengan lebih dari 37 mitra, lebih dari 100 nasabah dan mempekerjakan sebanyak 8 orang karyawan, dimana biasanya Aisyah hanya mempekerjakan karyawan yang merupakan penyandang disabilitas dengan tujuan memberikan ruang bagi mereka untuk berkarya.Bank Sampah NTB Mandiri didirikan sebagai bentuk keprihatinan akan banyaknya masyarakat, terutama yang tinggal di daerah sekitar kampung tempat Bank Sampah NTB Mandiri berada yang belum sadar terhadap pentingnya menjaga kebersihan lingkungan. Dengan adanya Bank Sampah NTB Mandiri ini, Mbak Aisyah berharap agar tidak hanya kesadaran masyarakat yang dapat terbentuk, tetapi juga mereka mampu mengelola sampah menjadi sesuatu yang bernilai jual tinggi bahkan bisa bersaing di tingkat internasional. Beruntung, selama beberapa tahun belakangan ini kegiatan di Bank Sampah NTB Mandiri mendapat dukungan dari pihak CSR PLN, yaitu PLN Peduli. (Hardiyanti, 2017)

Desa Sekotong Tengah sendiri merupakan salah satu desa yang berada dalam pemerintahan Kabupaten Lombok Barat, dan masih memiliki panorama alam dan kehidupan budaya yang cukup indah dan dijadika destinasi pariwisata. Selain itu desa Sekotong yang memiliki visi misi yaitu "Bersama Menuju Desa Sekotong Tengah yang Sejahtera, Cerdas, Sehat, dan Aman Tahun 2023". Namun hal ini belum sejalan dengan penataan desa sekotong yang masih sangat rendah, karena belum adanya sarana dan prasarana yang mendukungnya. Oleh karena itu mahasiswa KKN Infrastruktur Universitas Mataram 2018 mengadakan beberapa program kerja untuk mendukung berjalanya pembangunan yang memenuhi kriteria sanitasi lingkungan yang sehat di desa Sekotong Tengah (Data Umum Desa Sekotong Tengah, 2017).

\section{METODE}

Untuk merealisasikan visi misi serta tujuan yang ada maka dalam KKN di Desa Sekotong Tengah menggunakan Metode PAR (Participatory Action Research). PAR sendiri adalah suatu cara membangun jembatan untuk menghubungkan orang. Jenis penelitian ini adalah suatu proses pencarian pengembangan pengetahuan praktis dalam memahami kondisi sosial, politik, lingkungan, atau ekonomi. PAR adalah suatu metoda penelitian dan pengembangan secara partisipasi yang mengakui hubungan sosial dan nilai realitas pengalaman, pikiran dan perasaan kita.

Sedangkan berdasarkan metodelogi kerja PAR, ketiga variabel tersebut dirumuskan sebagai, Participatory, kedua item di atas dilaksanakan secata partisipasi artinya dengan melibatkan seluruh komponen masyarakat dalam melakukan identifikasi masalah serta teknik untuk mencari solusi secara bersama-sama dan melakukan secara bersama-sama pula bukan saja sebagai penonton atau gaya bos yang hanya bisa memerintah tetapi tidak bisa bekerja (talk less do more). Action atau aksi, setelah mengetahui masalah-masalah tersebut secara mendalam dan mendetail, barulah masuk dalam langkah yang kedua yaitu pencarian alternatif untuk memecahkan masalah tersebut yang kemudian diterjemahkan dalam beberapa item dalam program kerja yang akan dilaksanakan. Research atau penelitian, tahap ini merupakan penelitian tentang permasalahan yang dihadapi masyarakat, permasalahan tersebut dipahami sedemikian mendalam dan mendetail sehingga masalah tersebut bisa diketahui dengan jelas penyebab dan akibatnya. 
Untuk mengoptimalkan penelitian dimulai dengan tahap persiapan, observasi, sosialisasi, pelatihan dan pembinaan. Selain itu metode evaluasi pelaksanaan program kegiatan KKN ditinjau dari keberlangsungan program kerja dan keefektifan keberlangsungan program pada sasaran dari setiap program kerja.

\section{HASIL DAN PEMBAHASAN}

Pelaksanaan kegiatan Kuliah Kerja Nyata (KKN) di Desa Sekotong Tengah, diperlukan sebuah penyusunan program kerja yang dijadikan sebagai pedoman dasar dalam melaksanakan setiap kegiatan. Dengan demikian, realisasi program benar-benar sesuai dengan rencana dan mampu mencapai tujuan yang diinginkan. Dalam program yang dijalankan mahasiswa Universitas Mataram pada masa KKN terdiri dari 2 program utama dan 2 program tambahan.

Pada program Utama terdapat 2 program kerja yang dilaksanakan di Desa Sekotong Tengah, yaitu program kerja yang mencakup tema peningkatan dan pengolahan sanitasi berbasis infrastruktur pemukiman yang bernilai ekonomis. Dengan program kerja antara lain :

1. Pelatiahan Pembuatan Pupuk Kompos dari Kotoran Ternak

Program kerja ini sendiri bertujuan untuk memberikan pengetahuan cara pengolahan kotoran ternak menjadi pupuk kompos kepada warga khususnya kepada kelompok tani di desa Sekotong Tengah. Sanitasi kandang ternak yang masih sangat buruk membuat kotoran ternak hanya dibiarkan begitu saja tanpa ada pengelolaan lebih lanjut. Maka itu diadakanlah pelatihan dengan menghadirkan narasumber untuk mengisi pelatihan. Dengan adanya pelatihan warga desa Sekotong Tengah diharapkan mengetahui bahaya kotoran ternak yang dibiarkan begitu saja serta manfaat dari pengolahan kotoran ternak tersebut.

Tabel 1. Pelatihan Pengolahan Kotoran Ternak Menjadi Pupuk Kompos

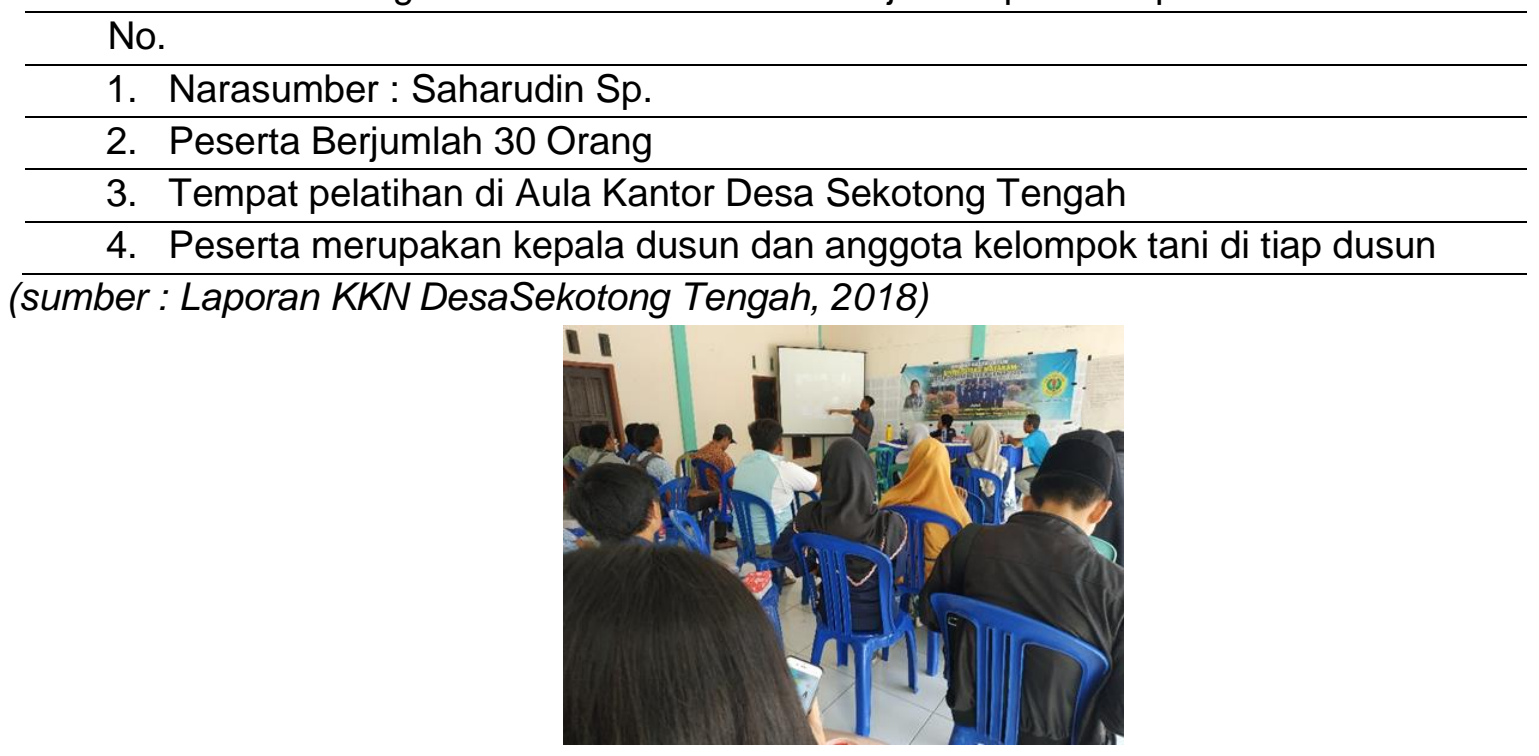

Gambar 1. Pelatihan pembuatan pupuk kompos

2. Pelatiahan Pembuatan Kerajinan Tanggan yang Bernilai Ekonomis dari Sampah Anorganik 
Pelatihan ini sendiri bertujuan untuk menambah wawasan serta kreatifitas untuk mengolah sampah Anorganik menjadi sesuatu yang bernilai ekonomiskepada warga yang di khususkan untuk remaja putri serta ibu-ibu di desa Sekotong Tengah. Pelatihan dilakukan 3 kali dengan kerajinan yang berbeda, yaitu kerajinan membuat bunga dari kantong plastic, membuat piring ingke dari cup kemasan minuman gelas, dan membuat gantungan kunci dari limbah kemasan yakult.

Tabel 2. Pelatihan Pembuatan Kerajinan Tangan yang Bernilai Ekonomis dari Sampah Anorganik

\begin{aligned} & \hline A. Kerajinan Membuat Bunga dari Sampah Kantong Plastik \\ & \hline 1. Narasumber : Lailatul Ulfah (Mahasiswa KKN) \\ & \hline 2. Peserta Berjumlah 50 Orang \\ & \hline 3. Tempat pelatihan di Pondok Pesantren Darul Qur'an Wal Hadist \\ & 4. Peserta merupakan Siswa pondok pesantren yang terdiri dari siswa Mts \\ & dan Madrasah \end{aligned}




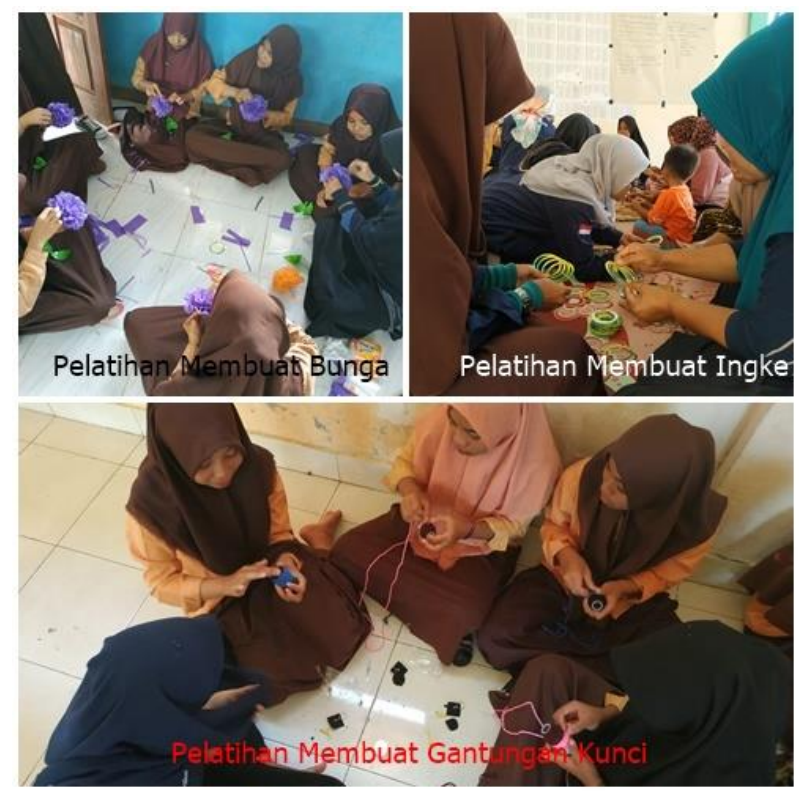

Gambar 2. Rangkaian Pelatihan Kerajinan Tangan dari Sampah Anorganik.

Sedangkan program kerja tambahan juga dilaksanakan dengan tema yang sama namun , yaitu Opimalisasi dan Perehabilitasan Sanimas yang berada di desa Sekotong Tengah. Program kerja ini bertujuan untuk merehab system sanimas yang ada sehingga dapat di gunakan kembali, rehabilitas yang di lakukan yaitu membersihkan dan memasang komponen yang sudah rusak antaralain keranair dan lampu. Diadakanya rehabilitas sanimas ini karena sanimas tidak difungsikan sejak awal tahun 2017 yang mengakibatkan sanimas terbengkalai. Oleh karena itu kami mengadakan rehabilitas pada area sanimas. Selain itu, dibangun juga bak sampah di beberapa titik desa.

Program tambahan kedua yaitu Gotong royong yang dilakukan setiap jum'at dan minggu, dengan tema "jum'at dana had bersih". Proker ini bertujuan untuk mengajarkan kepda mansyarakat pentingnya menjaga kebersihan.

Di dalam pelaksanaan program mahasiswa KKN menemui beberapa kesulitan, seperti susahnya mengumpulkan warga masyarakat yang menjadi sasaran kegitan dari program kerja yang telah dirancang, tidak tersedianya sarana perasarana yang mendukung pada beberapa program yang direncanakan. Dalam hal ini peran aparat desa sangat penting sebagai penghubung antar mahasiswa KKN dan masyarakat desa sehingga program dapat dilaksanakan dengan efektif. Setiap program yang dilaksanakan mendapat respon positif dari aparat desa dan masyarakat desa.

\section{KESIMPULAN DAN SARAN}

Berdasarkan hasil dan pembahasan yang sudah dijelaskan di atas, dapat disimpulkan bahwa dengan adanya program KKN di Desa Skotong Tengah secara umum dapat mengembangkan taraf hidup masyarakat dan kesadaran akan pentingnya kebersihan lingkungan, melalui program "Pengelolaan Sanitasi Lingkungan Berbasis Infrastruktur Pemukiman yang Bernilai Ekonomis" diharapkan membawa dampak positif bagi masyarakat sekitar yang awalnya barang-barang atau bahan-bahan yang dianggap tidak penting atau tidak berguna bisa dimanfaatkan atau didaur ulang kembali dan dapat bernilai ekonomis bila di jual atau digunakan sendiri. Misalnya piring ingke dapat 
digunakan sebagai wadah kue pada saat ada acara, kerajinan bunga dapat dijadikan hiasan, dan masih banyak lagi manfaat yang lain. kemudian bagi mahasiswa sendiri dalam kegiatan KKN Infrastruktur ini dapat menerapkan ilmu yang didapatkan di bangku perkuliahan untuk kemajuan khususnya di Desa Skotong Tengah. Dengan telah dilakukannya program-program yang sudah dijelaskan di atas maka diharapkan khususnya masyarakat Desa Skotong Tengah untuk bisa melanjutkan sindiri apa yang sudah mereka dapatkan dari mahasiswa KKN Infrastruktur Universitas Mataram.

\section{DAFTAR REFERENSI}

Badan Pusat Statistik. (2013). Bandung dalam Angka 2013. Bandung: Badan Pusat Statistik.

Berita Tksk Pidie. (2012). Masalah Kesehatan Di Desa-desa. http://beritatkskpidie.blogspot.com/2012/07/masalah-kesehatan-di-desadesa.html.<akses 1 November 2018>

Echols dan Shadily. (2003). Kamus Inggris Indonesia, Gramedia, Jakarta.

Hardiyanti, Andy. (2017). Lebih Dekat dengan Sampah di Bank Sampah NTB Mandiri. http://www.andyhardiyanti.com/2017/09/banksampah-ntb-mandiri/. < akses 8 November 2018 >

Kantor Desa Sekotong Tengah. (2017). Data Umum Desa Sekotong Tengah Tahun 2017. Lombok Barat.

Magfiroh, Ade Ramdan. (2016). Pemberdayaan Masyarakat Melalui Pengelolaan Sampah Organik (Komposting) oleh Akademi Kompos di Bumi Pesanggrahan Mas RW 08 Kelurahan Petukangan Selatan. http://repository.uinjkt.ac.id/dspace/bitstream/123456789/34609/1/ADE\%20RAMADHAN\%20MAGHFIROH-FDK.pdf. <akses 8 November 2018>

Mutmainna, Nurul. (2012), Masalah Kesehatan Lingkungan. Jakarta. https://www.scribd.com/doc/82680203/Makalah-KesehatanLingkungan. <akses 1 November 2018>.

Notoatmodjo, Soekidjo. (2003). IImu Kesehatan Masyarakat "Prinsip-prinsip dasar", Rineka Cipta, Jakarta.

Wahyudin, Susane. Hismi. (2018). Studi Sitem Pengelolaan Sampah Pasar Di Pasar Tradisional Pagesangan Kota Mataram. Sekolah Tinggi Teknik Lingkungan (STTL) Mataram. Mataram. 